\title{
Announcing a new series
}

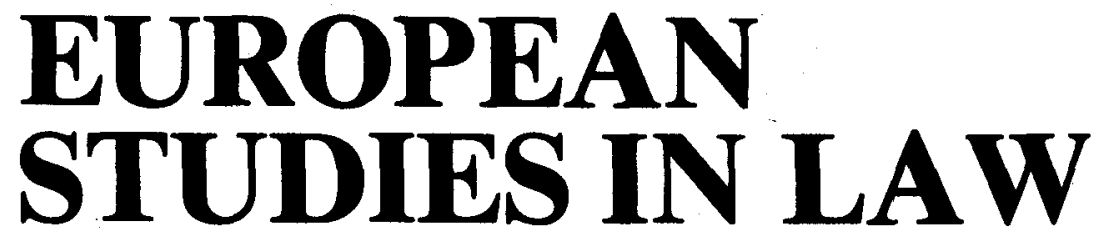

General Editor: A. G. CHLOROS, Professor of Comparative Law, Director, Centre of European Law, University of London, King's College.

The Centre of European Law of King's College in the University of London and North-Holland Publishing Company have pleasure in presenting this new series of Studies, which aims firstly at providing original studies in subjects or topics which have been encouraged by the growing interest amongst lawyers and legal scholars working beyond the frontiers of national law; and secondly at presenting, in a convenient form, legal material of high quality which, before, was not easily accessible to those engaged in teaching, research or legal practice.

The first 2 volumes have now been published:

\section{Vol. 1: COMPARATIVE CONFLICT OF LAWS.}

Selected Essays I, by R. H. GRAVESON, Univ. of London, King's College 1977. 398 pages. Dfl. $87.50 /$ US $\$ 35.75$

This book represents three decades of thinking and writing on private international law by a distinguished authority in common law. Professor Graveson offers a new and comparative approach to problems of private international law. He deals with the broad philosophical and historical bases, and analyses problems of special difficulty, such as those in non-unified systems. This is an indispensable work for comparative private international lawyers in any country.

\section{Vol. 2: ONE LAW. On Jurisprudence and the Unification of Law.}

Selected Essays II, by R. H. GRAVESON

1977. 304 pages. Dfl. $82.50 /$ US $\$ 33.75$

The three themes of this selection of essays, namely the author's theory of law, the character of the common law and the processes of unification of law, are all comprehended in the short title of One Law. This is not only an original theory and new insight into the common law, but a substantial treatment of the important contemporary problem of unification of law.

\section{Both volumes can also be purchased in a 2-volume set at} Dfl. 150.00/US $\$ 61.25$

Further volumes are in active preparation. A descriptive brochure on the series is available on request.

NORTH-HOLLAND PUBLISHING COMPANY

P.O. Box 211 - Amsterdam - The Netherlands

52 Vanderbilt Avenue-New York.N.Y. 10017.U.S.A.

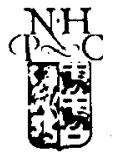




\title{
LAW OF THE SEA: CONFERENCE OUTCOMES AND PROBLEMS OF IMPLEMENTATION-Proceedings- Law of the Sea Institute-Tenth Annual Conference
}

\author{
Edward Miles, Institute of Marine Studies, University of \\ Washington and John King Gamble, Jr., The Pennsylvania \\ State University, Editors \\ Perspectives on current and future policies for the Law of \\ the Sea Group. \\ In preparation \\ ca. $\$ 20.00$
}

\section{SOFT ENERGY PATHS}

Toward a More' Durable Peace

Amory B. Lovins, Friends of the Earth, Inc.

(Published for Friends of the Earth, Inc.)

Based on his 1976 article in Foreign Affairs-which Energy Daily called "a seminal chapter in the history of energy policy"-Mr. Lovins proposes a coherent non-nuclear energy policy. This book, for the first time, ties all the issues together-engineering, economic, and thermodynamic concepts are thoroughly but concisely treated along with the social, environmental, and political perspectives.

In preparation ca. $\$ 15.00$ (cloth)

ca. $\$ 6.95$ (paper)

\section{FROM GUNS TO BUTTER}

Technology Organizations \& Reduced Military Spending in Western Europe

Bernard Udis, University of Colorado

How high technology organizationsparticularly aerospace, electronics and nuclear facilities-cope with declining defense budgets-includes an analysis of the nature of the military market for high technology systerns; effects of arms exports and government policies in support of civil science and technology; and the role of international relations.

In preparation

ca. $\$ 16.50$
INTERNATIONAL

ARRANGEMENTS FOR NUCLEAR FUEL PROCESSING

Abram Chayes, Harvard Law School and W. Bennett Lewis, Queens University, Editors

(Published for the American Academy of Arts and Sciences)

Papers presented at the International Pugwash Symposium-these multidisciplinary reports focus on the technical, political, and economic issues in multinational control of the nuclear reactor fuel cycle.

$\$ 15.00$

HIGH AND LOW POLITICS: INFORMATION RESOURCES FOR THE 80's

Anthony G. Oettinger and William $H$. Read, Harvard University and Paul J. Berman (Program on Information Resources Policy, Harvard University)

These essays trace the politics, economics and technology of telecom. munications pricing and costing policy and their impact on current communications policy; the interaction of old legal doctrines with newly combined computer and communications technologies and how these will affect FCC policy; the rapid growth of international telecommunications and its use in high and low politics as an instrument for policies shaping global interdependence.

$\$ 16.00$ 


\section{ALTERNATIVES TO GROWTH}

Dennis Meadows, Dartmouth College, Editor

Edited and revised papers from the 1975 Alternatives to Growth competition and conference including the four winners of the Mitchell Prize. They comprise a thoughtful summary of the current dimensions and imperatives on the question of how a modern society might be organized to provide a good life for its citizens without requiring ever-increasing population growth, energy resource use, and physical output.

In preparation

ca. $\$ 16.50$

\section{PROBLEMS OF WORLD MODELLING \\ Political and Social Implications}

Karl W. Deutsch, Harvard University, Bruno Fritsch, Swiss Federal Institute of Technology, Helio Jaguaribe, University of Candido Mendes, and Andrei $S$. Markovits, Harvard University, Editors

Focusing on major trends in world economics, politics and ecology, these papers offer concrete suggestions for planning and developing effective world models.

In preparation

ca. $\$ 17.50$

\section{TRACING THE MULTINATIONALS A Sourcebook on U.S.-Based Enterprises}

Joan P. Curhan, William H. Davidson, and Rahan Suri, Multinational Enterprise Project, Graduate School of Business Administration, Harvard University

Researchers and policymakers will find this book a valuable source of data for tracing in detail the growth and overseas spread of several hundred very large U.S. companies. The third in a series, it includes statistics on employment, sales, assets, exports and other activities for both country and industry levels through 1975.

In preparation

ca. $\$ 35.00$

\section{STALEMATE IN TECHNOLOGY}

Gerhard Mensch, International Institute of Management, Berlin

Originally published in Germany, this much acclaimed book links worldwide economic cycles-periods of growth and affluence as well as periods of recession-with innovations (or the lack of innovation) in technology. It offers convincing evidence of the need for constructive government policies which encourage research and development of basic innovations in new areas.

In preparation ca. $\$ 15.00$

THE JAPANESE ARE COMING:

A Multinational Interaction of Firms and Politics

\section{Yoshi Tsurumi, Harvard Business School}

The proliferation and success of Japanese multinational firms-their behavior in the perspective of the postWorld War II development of Japanhow their successes are dictating changes in Japan's industrial strategies and how these changes will affect future development and management of Japanese multinational firms.

$\$ 16.50$

\section{MILITARY EXPENDITURE LIMITATION FOR ARMS CONTROL: PROBLEMS AND PROSPECTS With a Documentary History of Recent Proposals}

Abraham S. Becker, The Rand Corporation

An analysis of the technical obstacles which prevent international agreement on limiting military expenditures. The author examines the economic, military and political issues which must be solved if expenditure limitation agreements among the major powers are to become a serious possibility.

In preparation

ca. $\$ 17.50$

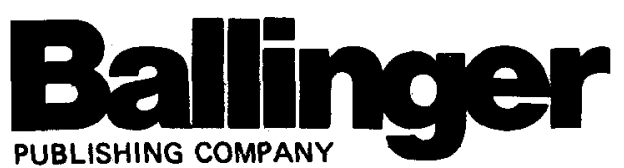

17 Dunster Street, Harvard Square, Cambridge, MA 02138 


\title{
Jnternational $\mathfrak{Z}$ aw Perspectibe
}

To the acclaim of international lawyers and scholars worldwide, International Law Perspective is a timesaving and highly informative monthly report available to all those who are interested and concerned with current developments in international law within the United States. Each issue selects, summarizes, and highlights the important and interesting occurrences in the Congress, the courts, the legal periodicals, and other notable sources. All monthly issues are sent by first-class mail.

Subscription for 12 issues: $0 . S . \&$ Canada, $\$ 36.00$; Foroign, $\$ 40.00$

\author{
Make check payable to: International Law Perspective \\ 927 15th Street, N.W. \\ Washington, D.C. 20005
}

\section{INNSBRUCK SEMINAR}

\section{January 7-21, 1978 Holiday Inn}

In cooperation with University of the Pacific, McGeorge School of Law, the California Continuing Education of the Bar, and the Faculty of Law of Innsbruck University, the Center for International Legal Studies will conduct a legal education seminar for practicing attorneys. The seminar, focusing on American Business Law, Commercial Law and Consumer Transactions, will utilize lectures and videotape presentations. An adjunct video program will examine developments in American Criminal Law, Family Law and Torts. Innsbruck University Faculty will provide a European perspective as to each topic. A complete ski program is included in the leisure-time program. For further information, contact:

\section{CENTER FOR INTERNATIONAL LEGAL STUDIES}

Postamt 5033 Salzburg, Austria Postfach 59 


\section{Herausgegeben von Professor Dr. Ignaz Seidl-Hohenveldern}

\section{Organisation internationaler Nutzsatellitensysteme}

Die Nutzung des Weltraums zu Kommunikationszwecken ist bewährte Praxis und von erheblichem wirtschaftlichen Gewicht. Weitere Nutzungsarten, insbesondere im Bereich der Informationsgewinnung über die Erde, stehen vor einer breiten, ökonomisch bedeutsamen Realisierung. Künstliche Erdtrabanten, etwa in Gestalt von Weltraumrelais, sind die tragenden Elemente solcher Weltraumnutzungen. Nutzsatelliten stehen in einem größeren technischen Funktionszusammenhang. Erst als Teil eines sogenannten Nutzsatellitensystems, das Satellitenbetriebs- und -kontrolleinrichtungen sowie Anlagen zur Benutzung des Satelliten umfaßt, sind diese operabel, d. h. als Nutzungsinstrumente verwendbar. Nutzsatellitensysteme können national oder international getragen sein. Die rechtliche Form und organisatorische Struktur multilateraler Satellitenunternehmungen sind Gegenstand der hier angezeigten Untersuchung, welche mit der von vierzig Staaten am 3. September 1976 in London gegründeten International Maritime Satellite Organization INMARSAT eine besondere Aktualität erhält. Der Autor gibt zunächst einen Uberblick über die physikalischen, technischen und juristischen Grundlagen der Weltraumnutzung sowie über deren wirtschaftliche Formen und Zwecke. Es folgt eine Beschreibung des Aufbaus und der Funktion von Nutzsatellitensystemen. Den Schwerpunkt der Arbeit bilden dann die Kapitel:

- Ziele und Praxis internationaler Weltraumnutzung;

- Völkerrechtlicher Rahmen internationaler Weltraumnutzung;

- Organisatorische Gestaltung internationaler Nutzsatellitenunternehmungen (Konstituierung, Strukturierung, Typisierung);

- Internationale Nutzsatellitenunternehmungen als services publics internationaux.

Bei der internationalen Weltraumnutzung handelt es sich um eine von Staatsregierungen gestaltete, betrieblich-technische Gemeinschaftsaktivität kapitalunternehmerischen Charakters. Die errichteten Nutzsatellitenorganisationen sind eine Spezialform Internationaler Unternehmen. Obzwar technische Organisationen, sind sie keineswegs auch unpolitisch. Ihre Ausstattung mit einem eigenen Betrieb, eben dem Satellitensystem, macht sie zudem zu operationellen Organisationen. Und die Art ihrer Tätigkeit läßt sich als unternehmerisch bezeichnen.

Diese interessante Neuentwicklung im Recht der Internationalen Organisationen wird im Anhang der Untersuchung durch den Abdruck der beiden INMARSAT-Gründungsabkommen vom 3. September 1976 dokumentiert. Die Veröffentlichung richtet sich sowohl an den Völkerrechtler wie auch an den Praktiker im staatlichen und industriellen Raumfahrtsektor.

$1977,143 \mathrm{~S} ., .15,3 \times 22,7 \mathrm{~cm}$, Salesta geb., 39,- DM

ISBN $3-7890-0266-6$

Nomos Verlagsgesellschaft

Postfach $610 \cdot 7570$ Baden-Baden

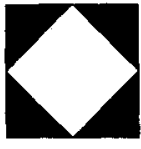




\section{International Law}

\section{A Current Bibliography of Articles}

Bibliography compiled by collaborators of the Max Planck Institute under the direction of Werner Morvay and Lothar Gündling

Editors: Hermann Mosler and Rudolf Bernhardt, Max Planck Institute for Comparative Public Law and International Law

This systematic bibliography of public international law fills a previously existing lacuna in the documentation of legal literature. Scheduled to appear regularly at six-month intervals, it. is based on a comprehensive classification scheme developed by the staff of the Max Planck Institute (MPI). Its aims are twofold: to enable the reader to follow the literature with regard to developments in specialized areas and to facilitate through its computer-produced index the retrieval of literature from the whole field of public international law. The basis for the compilation of this well-devised bibliography is the comprehensive holdings of the MPI library, where journals and other collective works are immediately screened upon receipt by members of the institute's scientific staff. Even journals that contain only occasional contributions to public international law are taken into account, and thus the usefulness of the bibliography is further enhanced. Case notes and book reviews that provide original contributions to the subject matter are also included.

\section{Subscription Information:}

Vol. 1, 1975, Vol. 2, 1976 and Vol. 3, 1977 (2 issues each)

Price of annual Volume $\$ 21.90$, including postage and handling.

Members of the American Society of International Law are entitled to subscribe to Public International Law for $\$ 16.00$, including postage and handling.

Subscriptions are entered with prepayment only.

To order, or obtain additional information or sample copies, contact:

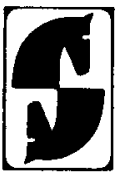

Springer-Verlag New York Inc.

Subscription Department

175 Fifth Avenue

New York, NY 10010

Springer-Verlag Berlin Heidelberg New York 


\section{THE SAN DIEGO LAW REVIEW announces \\ LAW OF THE SEA SYMPOSIUM IX}

Arvid Pardo (Professor of Political Science, University of Southern California) Foreword

John Norton Moore (Walter L. Brown Professor of Law, Director, Center for Oceans Law and Policy, University of Virginia) Introduction: Next Steps Toward a Law of the Sea in the Common Interest.

Thomas A. Clingan, Jr. (Professor of Law, University of Miami Law School) Emerging Law of the Sea: The Economic Zone Dilemma.

Carl August Fleischer (Professor of Law, Special Consultant to the Norweigan Ministry of Foreign Affairs) The Right to a 200-Mile Exc/usive Economic Zone or a Special Fishery Zone.

Elisabeth Mann Borgese (Associate, Center for the Study of Democratic Institutions, Pacem in Maribus) The New International Economic Order and the Law of the Sea.

A.V. Lowe (Professor of Law, University of Wales Institute of Science and Technology) The Right of Entry into Maritime Ports in International Law.

Jack N. Barkenbus (Oak Ridge Institute for Energy Analysis) Seabed Negotiations: The Failure of United States Policy.

Subcommittee on International Relations of the Advisory Committee on the Law of the Sea, Afterword: Third United Nations Conference of the Law of the Sea.

Comment, UNCLOS III: Last Chance for Landlocked States?

Comment, Hot Pursuit from a Contiguous Fisheries Zone -An Assault on the Freedom of the High Seas.

Comment, Kiev and the Montreux Convention: The Aircraft Carrier that became a Cruiser to Squeeze through the Turkish Straits.

Synopsis, Recent Developments in Law of the Sea: 19751976.

For a copy of Symposium IX or previous LOS Symposia send $\$ 7.50$ per symposium to: 


\section{The Common Law Zone in Panama \\ A Case Study in Reception \\ by Wayne D. Bray \\ The first comprehensive survey in book form seen from an historical perspective of the legal problems involved in the Panama Canal Zone, clearly showing the relevance of that history to contemporary concerns, including current treaty controversy. Of special interest to historians, government officials, lawyers, and Latin Americanists. \\ LC 76-23354 ISBN 0-913480-35-5 $\$ 20.00$ \\ Inter American University Press GPO Box 3255, San Juan, Puerto Rico 00936}

\section{The American Political Science Review and PS}

Institutional membership in the American Political Science Association offers subscribing members two journals, The American Political Science Review and PS.

The Review is the scholarly journal of the Association and includes articles covering comparative and American government, administration, public law, international relations, and political theory. An extensive book review section is also included.
$P S$ is the Association's news journal with invormation on professional developments, research and study support, and professional as well as Association activities. Articles and reports on the discipline and profession are also included.
Annual Institutional

Membership (includes subscription to two journals)

Domestic Institutions Annually $\$ 50.00$

Foreign Institutions 


\section{Join-}

\section{THE AMERICAN SOCIETY OF INTERNATIONAL LAW}

As a momber of the Society, you will receive

- four issues each year of the most distinguished journal in the field, THE AMERICAN JOURNAL OF INTERNATIONAL LAW.

- the PROCEEDINGS of the Society's Annual Meeting.

- the opportunity to buy other Society publications at reduced prices, such as the valuable bimonthly documentary, INTERNATIONAL LEGAL MATERIALS, and books published under Society auspices such as THE VIETNAM WAR AND INTERNATIONAL LAW.

- the Society's NEWSLETTER, which keeps you abreast of developments in the field.

- the opportunity to participate in significant, Society-sponsored meetings (the Annual Meeting, regional meetings, study panels).

- occasion to join with others in contributing to the development of international law through the Society's wide-ranging studies and publications.

If you wish to join the Society, please clip out this page, fill out the applica. tion on the reverse side, and mail it, together with your check, to the Membership Secretary, American Society of International Law, 2223 Massachusetts Avenue, N.W., Washington, D. C. 20008. You will receive the Journal and Newsletter for the current year.

Members of whatever profession and nationality are welcome.

If you or your institution prefers to subscribe to the Journal, without joining the Society, please so indicate on the reverse side. 
Membership Secretary

American Society of International Law

2023 Massachusetts Avenue, N.W.

Washington, D.C. 20008

Please enroll me as a member of the American Society of International Law. My check, money order, UNESCO coupon, or payment in a convertible currency, is enclosed. I have checked the category of membership for which I am eligible:

[ ] PROFESSIONAL MEMBERS (U.S. residents practicing law other than in government who have been members of the bar for more than 10 years ) $\ldots \ldots \ldots \ldots \ldots \ldots \ldots \ldots \ldots \ldots \$ 40$

[ ] RESIDENT REGULAR MEMBERS-residing in the United

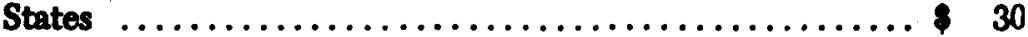

[ ] NON-RESIDENT MEMBERS-not residing in the United States

l ] INTERMEDIATE MEMBERS (first 5 years of membership for those under 30 years of age at time of application) . . $\$ 15$

I ] STUDENT MEMBERS $\ldots \ldots \ldots \ldots \ldots \ldots \ldots \ldots \ldots \ldots \ldots \ldots \& 10$

I ] CONTRIBUTING MEMBERS $\ldots \ldots \ldots \ldots \ldots \ldots \ldots \ldots \ldots \& 50$

I ] SUPPORTING MEMBERS $\ldots \ldots \ldots \ldots \ldots \ldots \ldots \ldots \ldots \ldots \& 100$

[ ] ANNUAL PATRON $\ldots \ldots \ldots \ldots \ldots \ldots \ldots \ldots \ldots \ldots \ldots \ldots \$ 500$

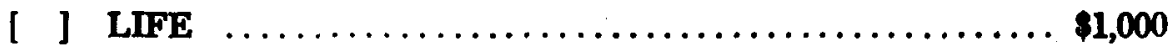

(\$15 of membership fee is allotted to AJIL mubscription)

(Please Print)

Name

Mailing Address

Professional Affliation:

Nationality

Particular professional interests:

Signature

PLEASE MAKE CHECKS PAYABLE TO The American Soclety of International Law. Contributions above obligatory dues, and all dues if membership is related to your work or profession, are tax deductible in the United States.

Please enter my subscription for the Journal at $\$ 36$ a year 